\title{
DOE/PC/91008--23-Pt.7 \\ Reserve and Production Data for the Andector \\ Field Area, Central Basin Platform, West Texas: \\ Data for Model Constraint and Development
}

K. Sundberga, T. Hoak ${ }^{b}$, and P. Ortoleva ${ }^{c}$

a Phillips Petroleum Company

252 Geoscience Building

Bartlesville, Oklahoma 74003

b Kestrel Geoscience, LLC

9683 West Chatfield Avenue, Unit D

Littleton, Colorado 80128

c Laboratory for Computational Geodynamics

Department of Chemistry

Indiana University

Bloomington, Indiana 47405 


\section{DISCLAIMER}

Portions of this document may be illegible in electronic image products. Images are produced from the best available original document. 


\section{Table of Contents}

Summary

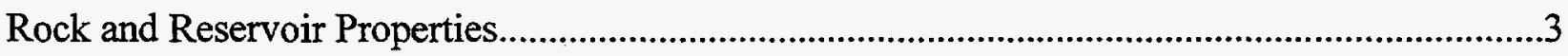

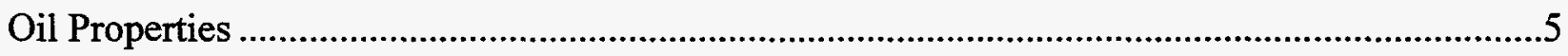

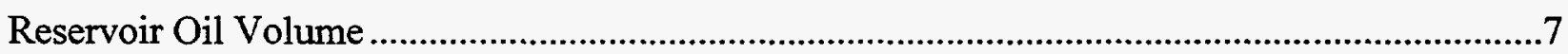

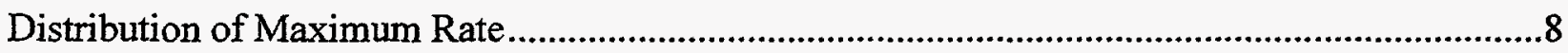

Remaining Hydrocarbon Potential or Primary Reserves ............................................................

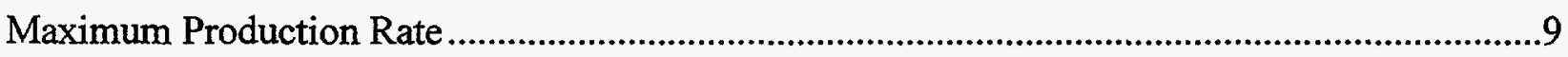

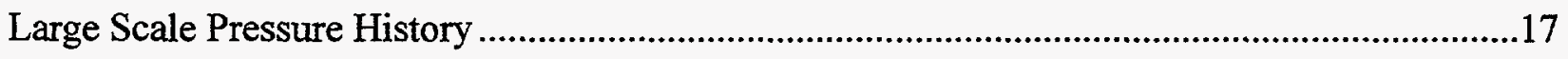

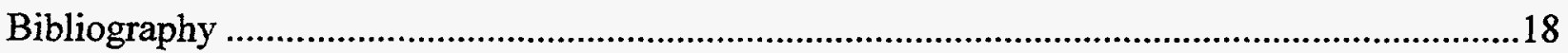

\section{DISCLAIMER}

This report was prepared as an account of work sponsored by an agency of the United States Government. Neither the United States Government nor any agency thereof, nor any of their emplcyees, makes any warranty, express or implied, or assumes any legal liability or responsibility for the accuracy, completeness, or usefulness of any information, apparatus, product, or process disclosed, or represents that its use would not infringe privately owned rights. Reference herein to any specific commercial product, process, or service by trade name, trademark, manufacturer, or otherwise does not necessarily constitute or imply its endorsement, recommendation, or favoring by the United States Government or any agency thereof. The views and opinions of authors expressed herein do not necessarily state or reflect those of the United States Government or any agency thereof. 


\title{
RESERVE AND PRODUCTION DATA FOR THE ANDECTOR FIELD AREA, CENTRAL BASIN PLATFORM, WEST TEXAS: DATA FOR MODEL CONSTRAINT AND DEVELOPMENT
}

\author{
K. R. Sundberg, Phillips Petroleum Co., Bartlesville OK, \\ T. E. Hoak, SAIC and Kestrel Geoscience, LLC, Littleton CO, \\ P. Ortoleva, Laboratory for Computational Geodynamics, Indiana University, \\ Bloomington, IN
}

\begin{abstract}
Summary
The integrated model under development will ultimately predict reservoir properties, volumes, fluid content, and fluid composition (water, oil, and gas). Oil properties are presented here for use in subsequent flow models. To further constrain and verify these predictions, production history data, reservoir geometry, and well test data are used to map the initial potential, remaining reserves, and maximum non allowable limited production rates of the Andector Field. Historic bottom hole pressure data illustrate early production interference and boundary effects.
\end{abstract}





\section{RESERVE AND PRODUCTION DATA FOR THE ANDECTOR FIELD AREA, CENTRAL BASIN PLATFORM, WEST TEXAS: DATA FOR MODEL CONSTRAINT AND DEVELOPMENT}

Reservoir data related to the CIRF.B model concerns the ability of the rocks in a field to deliver oil. Naturally, the flow properties of the fluids bear on this problem as do the flow characteristics of the rocks. In addition, for matching purposes, we include data on

(1) the maximum observed production rate for the field in pseudo-steady-state decline,

(2) the initial potential as determined in well tests, and

(3) a characterization of the pseudo-steady-state decline rates over the field.

The potential and rate data are interpretations of commercially available data [Petroleum Information Industry Client Server (PICS, 1997)]. The rock and fluid data are from corporate documents (Technical Committee, 1972).

\section{ROCK AND RESERVOIR PROPERTIES}

The Andector reservoir rocks are in the Ellenburger Group of West Texas. Table 1 summarizes their physical properties.

Table 1. General rock properties for the study area of West Texas.

\begin{tabular}{llll}
\hline Property & Value & \multicolumn{1}{l}{ Condition } \\
\hline & & & \\
Porosity (\%) & $0-3 \%$ & $150 \mathrm{ft}$ & Phillips Alma \# 7 \\
& $3-5 \%$ & $173 \mathrm{ft}$ & $9,468 \mathrm{ft}$ to $9,872 \mathrm{ft}$ \\
& $5-8 \%$ & $63 \mathrm{ft}$ & \\
& $8-10 \%$ & $11 \mathrm{ft}$ & \\
& $10-15 \%$ & $4 \mathrm{ft}$ & \\
& $15+\%$ & $1 \mathrm{ft}$ & \\
& $3.8 \%$ & & Average \\
Permeability & Unknown & \\
So & 0.7 & & \\
Pressure & 3485 & psi & $5120 \mathrm{ft}$ datum \\
& & & \\
\hline
\end{tabular}

This reservoir rock is a fractured dolomite. The fractures are of karst and subsequent tectonic origin and are highly cemented (see fracture report section of this document). 



\section{OIL PROPERTIES}

The Andector oils are typical of the Ellenburger Group of West Texas. Table 2 summarizes their physical properties.

Table 2. General oil properties for the study area of West Texas.

\begin{tabular}{|c|c|c|}
\hline Property & Value & Condition \\
\hline Oil gravity & $44^{\circ} \mathrm{API}$ & $60^{\circ} \mathrm{F}$ \\
\hline Gas Gravity & 1.05 & \\
\hline Water Salinity & $21,736 \mathrm{ppm} \mathrm{Cl}^{-}$ & \\
\hline Saturation Pressure & $1105 \mathrm{psi}$ & $132^{\circ} \mathrm{F}$ \\
\hline Gas Solubility & $600 \mathrm{scf} / \mathrm{bbl}$ & \\
\hline \multirow[t]{3}{*}{ Formation Volume Factor } & 1.325 & 3,407 psi \\
\hline & 1.355 & $1,105 \mathrm{psi}$ \\
\hline & 1.258 & 500 psi \\
\hline \multirow[t]{3}{*}{ Oil Viscosity at $132^{\circ} \mathrm{F}$} & $0.67 \mathrm{cps}$ & 3,407 psi \\
\hline & $0.56 \mathrm{cps}$ & 1,105 psi \\
\hline & $1.56 \mathrm{cps}$ & 500 psi \\
\hline \multirow[t]{12}{*}{ Oil Composition } & 0.1872 & Methane \\
\hline & 0.1139 & Ethane \\
\hline & 0.1111 & Propane \\
\hline & 0.0135 & i-Butane \\
\hline & 0.0645 & n-Butane \\
\hline & 0.0106 & i-Pentane \\
\hline & 0.0510 & n-Pentane \\
\hline & 0.0491 & Hexane \\
\hline & 0.3838 & $\mathrm{C}_{6}+$ (Hexane+) \\
\hline & 0.0004 & Hydrogen Sulfide \\
\hline & 0.0059 & Nitrogen \\
\hline & 0.0090 & Carbon Dioxide \\
\hline Molecular Weight & 102.64 & \\
\hline Molecular Weight $\mathrm{C}_{6}+$ & 202.00 & \\
\hline
\end{tabular}

This oil is approximately a black oil, and it will be treated as such in the model studies of this project. 



\section{RESERVOIR OIL VOLUME}

The Andector reservoir was predicted to ultimately produce the oil volumes shown below.

Table 3. Produced oil from Andector area leases, see Figure 1 for locations, and predictions of producible oil form previous work.

\begin{tabular}{|c|c|c|c|c|c|c|}
\hline & & & roduction & rels $(000$ & & \\
\hline Tract & Lease & $\begin{array}{l}\text { Cum } \\
\text { to } 72^{\#}\end{array}$ & $\begin{array}{r}\text { Primary } \\
\text { to } 72 \\
\end{array}$ & $\begin{array}{c}\text { Cum } \\
\text { to } 98^{\#}\end{array}$ & $\begin{array}{r}\text { Predicted } \\
\text { Tot } \\
\end{array}$ & $\begin{array}{l}\text { Differ- } \\
\text { ence }\end{array}$ \\
\hline 1 & R. B Cowden E & 2130 & 781 & 2223 & 2911 & 688 \\
\hline 2 & R. B. Cowden B & 257 & 37 & 257 & 294 & 37 \\
\hline 3 & R. B. Cowden 12 & 3892 & 857 & 4440 & 4749 & 309 \\
\hline 4 & Limpia & 4228 & 2932 & 7034 & 7160 & 126 \\
\hline 5 & Nobles & 2645 & 1338 & 3925 & 3983 & 58 \\
\hline 6 & Cowden A & 2670 & 14 & 2674 & 2684 & 10 \\
\hline 7 & Abell & 3974 & 1582 & 4809 & 5556 & 747 \\
\hline 8 & Cowden $\mathrm{H}$ & 2443 & 20 & 2444 & 2463 & 19 \\
\hline 9 & Frank B & 9365 & 9274 & 18291 & 18639 & 348 \\
\hline 10 & Cummins 12 & 11399 & 5516 & 16074 & 16915 & 841 \\
\hline 11 & J. F. Cowden & 13558 & 16164 & 22661 & 29722 & 7061 \\
\hline 13 & Cummins 13 & 2077 & 297 & 2225 & 2374 & 149 \\
\hline 14 & Frank A & 8080 & 4083 & 10883 & 12163 & 1280 \\
\hline 15 & McEntire & 4195 & 4720 & 7383 & 8915 & 1532 \\
\hline 12 & Embar 9 & & & & & \\
\hline 16 & Embar $17^{*}$ & 17457 & 35038 & 36906 & 52495 & 15589 \\
\hline 17 & Embar 16 & & & & & \\
\hline 18 & Cowden C & 6753 & 156 & 7703 & 2304 & -794 \\
\hline 19 & Cowden C & 8658 & 4153 & 10507 & 12811 & 2304 \\
\hline 20 & Schar & 748 & 8 & 748 & 756 & 8 \\
\hline Total & & 104529 & 86970 & 161187 & 191499 & 30312 \\
\hline
\end{tabular}

\# Data are derived from PIICS.

*Embar 17 represents the sum of contributions for Embar 9, 16, and 17. This gives consistency between the commercial and corporate data.

Two things are apparent. First, the overall quality of the 1972 predictions of the Andector engineering team is exceptionally good. One can see where additional potential lies, and can begin to engineer the final production of the reservoir using these data.

Second, the reservoir is near ultimate depletion. For purposes of the basin analysis here, 
we can take the reservoir volume to be equal to the pre 1971 cumulative production plus the cumulative total prediction in tables 3 . This value is expressed as

Volume Recoverable Oil in Place (barrels) =

$100,870,000$ cumulative to ' $71+86,970,000$ predicted remaining post ' 71

$=$

$190,840,000$

This figure includes the volume of oil produced between 1949 (start of production) and 1958 (start of commercial data). The pre 1958 production has not been allocated to leases. Reservoir pore volume is approximately $500 * 10^{6}$ barrels, so the overall recovery is expected to be $38 \%$.

\section{DISTRIBUTION OF MAXIMUM RATE}

The leases in the Andector area have undergone a complicated production history. A typical production rate curve has the form shown below.

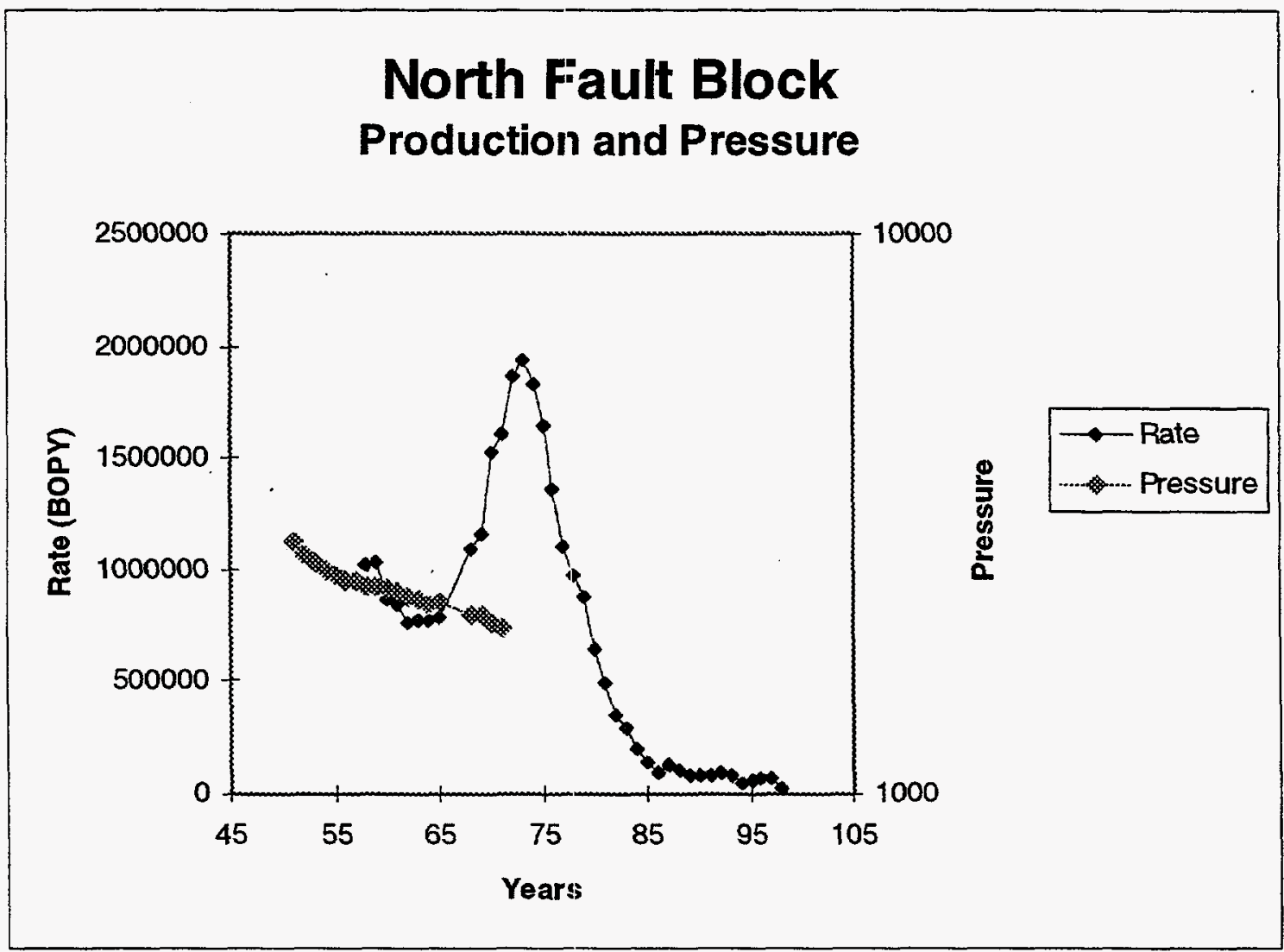

Figure 1. Pressure and production rate histories of a portion of the Andector Field. The ptressure data are from corporate sources, the rate data are from PIICS. The commercial rate data are not available for the times before 1958 . 
In light of these curves, we can assume:

(1) Before 1965, the production was limited, and the field was undergoing transient decline or near transient decline.

(2) After 1968, the field production practices radically changed. The pressure decline became more rapid, and the production rose to a maximum and went into a steep decline. Portions of the early part of this second decline are probably simple pseudosteady-state, and decline parameters may be estimated.

(3) It is likely that only a few and relatively minor modifications to production practices were made during the early part of this decline during the pre- 1968 period.

(4) The field was developed on a constant 40 acre spacing, so the pre-1968 portion of the pressure curve is the field's response to a uniform depletion over its entire area. After this period, wells are being shut in, rates are changing, and the analysis would require a great deal of complicated reinitialization.

\section{REMAINING HYDROCARBON POTENTIAL OR PRIMARY RESERVES}

Figure 2 below shows the remaining hydrocarbon potential for this area. Not surprisingly, this distribution follows structure. The largest reserves are just located where the oil saturated reservoir formation is thickest.

\section{MAXIMUM PRODUCTION RATE}

Figure 3 below shows the maximum production rates by lease observed over the area. One can see the field divides into North and South Fault blocks. The numbers are early production rates in barrels of oil per year for selected leases in the Andector area. The values are normalized to $1 \mathrm{mi}^{2}$ of lease area. The posted values are the annual rates for the first year of commercial data, 1958. This year is in the transient flow period, and all the subsequent transient flow rates (that is, rates prior to 1965) are less than those for 1958. Therefore, we take the 1958 rates to represent our best view of the reservoir's early rate potential. The well spacing in this field is 40 acres, and it is quite uniform over the area. The area normalization produces a property characteristic of the producing formation.

Figure 4 is similar to Figure 3. However, we plot the maximum post 1969 rate divided by the area of the lease. This is the rate achieved after the field was worked over from 1965 to 1970 and production practices changed to maximize yield. These numbers approximate the maximum rate the reservoir could produce at the onset of pseudo-steadystate flow. As for Figure 3, the area normalization produces a property characteristic of the producing formation.

Figure 5 shows the rates of Figure 4 normalized by the volume of the original oil in place. These numbers give an indication of the lifetime one might expect of the lease. The higher the rate relative to the oil present, the shorter the lifetime. 

The maximum rates in both Figures 3 and 4 naturally occur on the culminations of the structures. High rates are also seen in areas near the major bounding faults. The lowest rates are seen on the edges of the reservoir near the oil-water contact. In Figures 4 and 5, some of the rates are zero. These leases are marginal, small, and near the oil water contact. They tend to deplete before the larger, more important leases in the area go into true decline. These relations are not surprising, but they do suggest some structural control over the development of permeability.

The data on these maps is summarized in Table 3.

Table 3. Andector production data. Areas, isopachs, and production data are approximate from corporate data and commercial data sources. Isopachs are from visual averages of an isopach map. Areas are from graphic integration of area in lease boundaries. Approximate data are sufficient to constrain a basin model.

\begin{tabular}{|c|c|c|c|c|c|c|c|c|c|c|}
\hline Lease & $\begin{array}{l}\text { Area } \\
\text { mi2 }\end{array}$ & $\begin{array}{c}\text { Isopach } \\
\mathrm{ft}\end{array}$ & $\begin{array}{c}\text { Tot Vol } \\
\text { acre }\end{array}$ & $\begin{array}{c}\text { Vol } \\
\text { acre*ft }\end{array}$ & $\begin{array}{c}\text { OOIP } \\
\text { bbl }\end{array}$ & $\begin{array}{l}\text { Max } \\
\text { BOPY }\end{array}$ & $\begin{array}{c}\text { MaxRate } \\
\text { / mi2 }\end{array}$ & $\begin{array}{c}\text { Ratel } \\
\text { Vol }\end{array}$ & $\begin{array}{c}\text { MaxRate } \\
\text { / OOIP }\end{array}$ & $\begin{array}{c}\text { Rate'58i } \\
\text { Area }\end{array}$ \\
\hline R B COWDEN & 0.25 & 375 & 60000 & 2280 & $9.34 t+06$ & 0 & 0 & 0 & 0.000 & 115932 \\
\hline CUMMINS-12 & 0.95 & 300 & 182400 & 6931 & $2.84 €+07$ & 501764 & 528173 & 72 & 0.018 & 449508 \\
\hline CUMMINS-13 & 0.30 & 200 & 38400 & 1459 & $5.98 \mathrm{t}+06$ & 66076 & 220253 & 45 & 0.011 & 305327 \\
\hline COWDEN, R.B.-E & 0.20 & 300 & 38400 & 1459 & $5.98 €+06$ & 110562 & 552810 & 76 & 0.018 & 305425 \\
\hline COWUEN, R. B. -H- & 0.25 & 225 & 36000 & 1368 & 5.61 七 +06 & 0 & 0 & 0 & 0.000 & 278928 \\
\hline ABELLL & 0.25 & 300 & 48000 & 1824 & $7.48 €+06$ & 245239 & 980956 & 134 & 0.033 & 490300 \\
\hline BLAKENEY & 0.20 & 100 & 12800 & 486 & $1.99 E+06$ & 0 & 0 & $u$ & 0.000 & $1402 b 0$ \\
\hline EMBAR & 1.25 & 625 & souovo & 19000 & 1.r9ヒ+U/ & 1824002 & 1459202 & 96 & 0.023 & 465898 \\
\hline FRANK-A- & 0.65 & 210 & 87360 & 3320 & $1.36 \mathrm{t}+07$ & 519129 & 798660 & 156 & 0.038 & 426206 \\
\hline FRANK -B- & 0.55 & 475 & 167200 & 6354 & $2.60 €+07$ & 914690 & 1663073 & 144 & 0.035 & 561764 \\
\hline LIMPIA & 0.25 & 425 & 68000 & 2584 & $1.06 \mathrm{t}+07$ & 372880 & 1491520 & 144 & 0.035 & 495744 \\
\hline MCENTIRE & 0.25 & 475 & 76000 & 2888 & $1.18 \mathrm{t}+07$ & 370938 & 1483752 & 128 & 0.031 & 498488 \\
\hline NOBLES & 0.20 & 350 & 44800 & 1702 & $6.98 \mathrm{t}+06$ & 191364 & 956820 & 112 & 0.027 & 444040 \\
\hline SCHAR-B & 0.06 & 200 & 8006.4 & 304 & $1.25 t+06$ & 41021 & 655811 & 135 & 0.033 & 492134 \\
\hline COWDEN, R. B.12 & 0.03 & 200 & 3200 & 122 & $4.98 \mathrm{t}+05$ & 186751 & 7470040 & 1536 & 0.375 & 4894880 \\
\hline COWDEN-A & 0.25 & 200 & 32000 & 1216 & $4.98 \mathrm{t}+06$ & 0 & 0 & 0 & 0.000 & 279276 \\
\hline COWDEN-B & 0.06 & 300 & 12000 & 456 & $1.87 t+06$ & 38563 & 617008 & 85 & 0.021 & 482256 \\
\hline COWDEN, W. F. C. DEEP R/A & 0.75 & 150 & 72000 & 2736 & $1.12 \mathrm{t}+07$ & 548822 & 731763 & 201 & 0.049 & 305511 \\
\hline COWDEN, W. F. C.-DEEP R/A & 0.30 & $12 b$ & 40000 & 1320 & $6.231+06$ & 9us62 & 181124 & 60 & 0.015 & 204636 \\
\hline COWDEN, J. F. & 0.60 & 250 & 96000 & 3648 & $1.50 \mathrm{E}+07$ & 1152952 & 1921587 & 316 & 0.077 & 711443 \\
\hline Total, Average & 7.80 & 145 & $1.62 k+06$ & 61658 & $2.53 t+08$ & & & & & \\
\hline
\end{tabular}




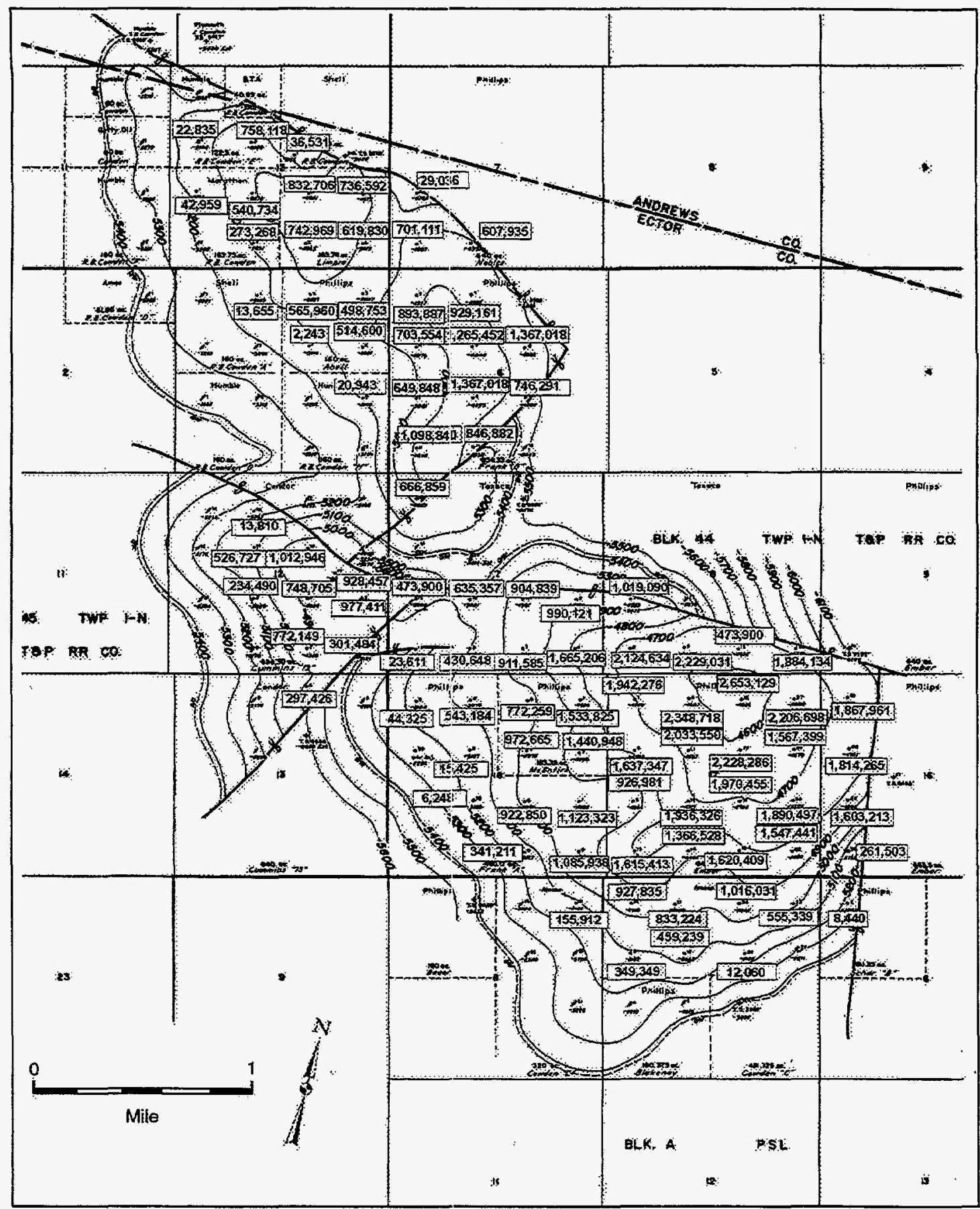

Figure 2. Remaining hydrocarbon reserves for selected wells in the Andector area. The map also shows the Ellenburger contours at sea level datum. 


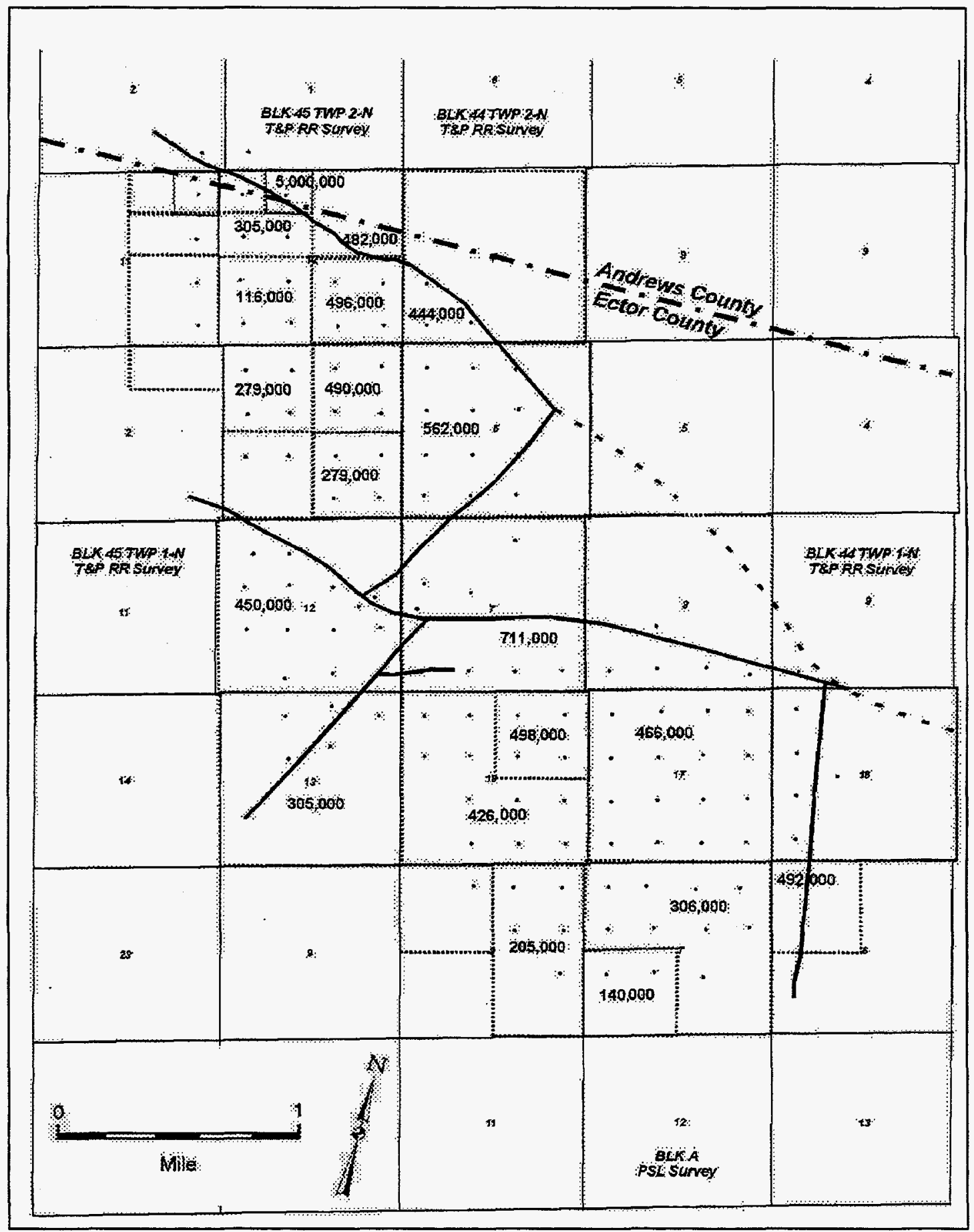

Figure 3. Early production rate in barrels of oil per year per $\mathrm{mi}^{2}$ of lease area for selected leases in the Andector area. The posted values are the annual rates divided by the lease area for the first year of commercial data, 1958. This year is in the transient flow period, and all the subsequent transient flow rates (that is, rates prior to 1965) are less than those for 1958. Therefore, we take the 1958 rates to represent our best view of the reservoir's initial rate potential. 


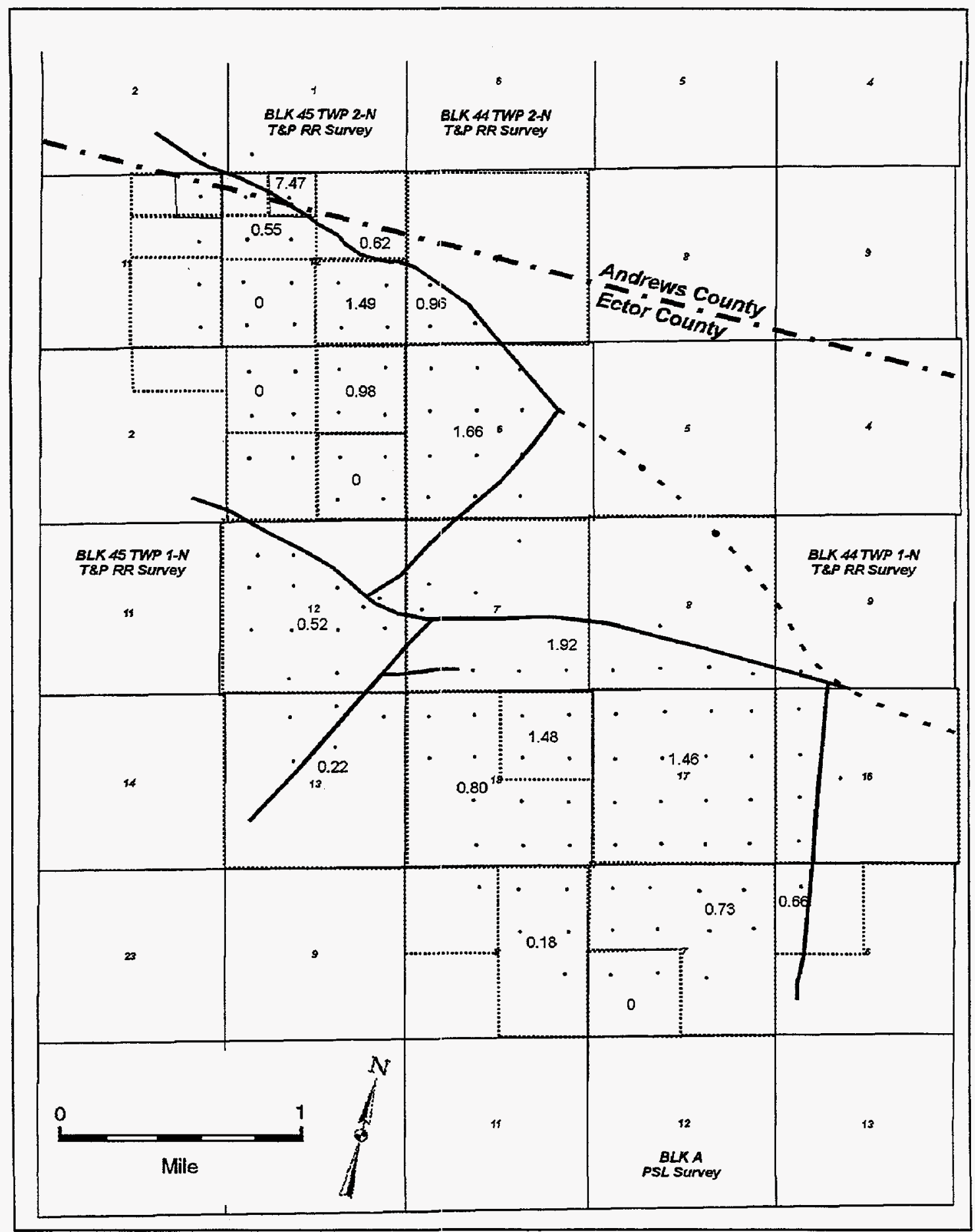

Figure 4. . Maximum apparent pseudo-steady-state rate in $1.0 * 10^{6}$ barrels of oil per year per $\mathrm{mi}^{2}$ reservoir area for selected leases in the Andector area. The posted values are highest the annual rates of production in the early 1970's divided by the reservoir area. The wells had all gone into pseudo-steady-state production at this time. The field was fully developed at a 40 acre spacing. This year is in the pseudo-steady-state when the pressure transients have definitely touched the reservoir walls and are in active interference. 


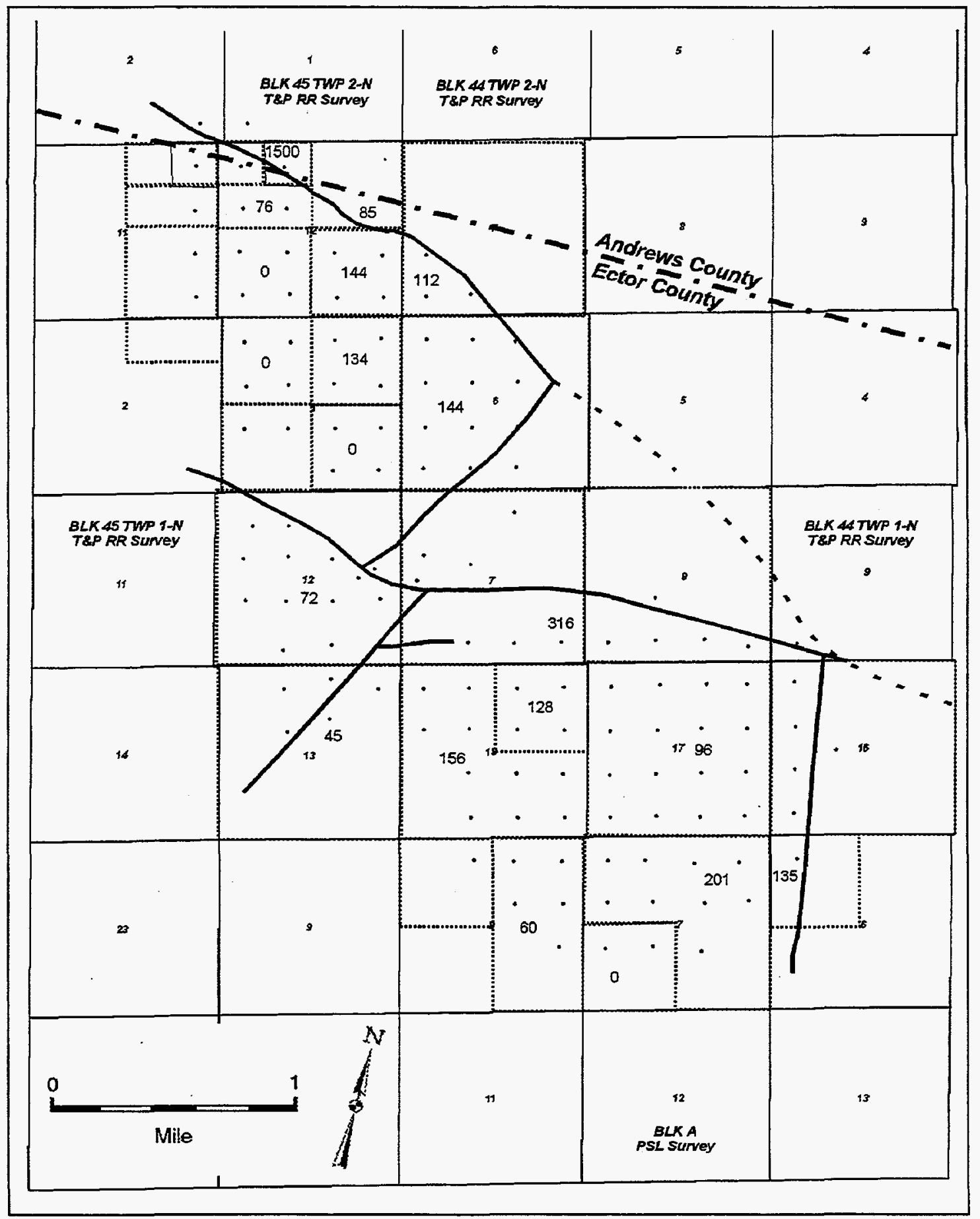

Figure 5. Maximum apparent pseudo-steady-state rate in $1.0 * 10^{6}$ barrels of oil per year per acre* $\mathrm{ft}$ reservoir volume for selected leases in the Andector area. The posted values are the highest annual rate of production in the early 1970's divided by the reservoir volume. The wells had all gone into pseudo-steady-state production at this time. The field was fully developed at a 40 acre spacing. This year is in the pseudo-steady-state when the pressure transients have definitely touched the reservoir walls and are in active interference. 



\section{LARGE SCALE PRESSURE HISTORY}

The following graphs show Cartesian plots of the pressure and rate history in an Andector Block. Figure 1 gaves the pressure history for and average of several wells in the North Fault Block area. Similar curves are available for other locations, and these curves are collected in Appendix I. The curves all have this basic form.

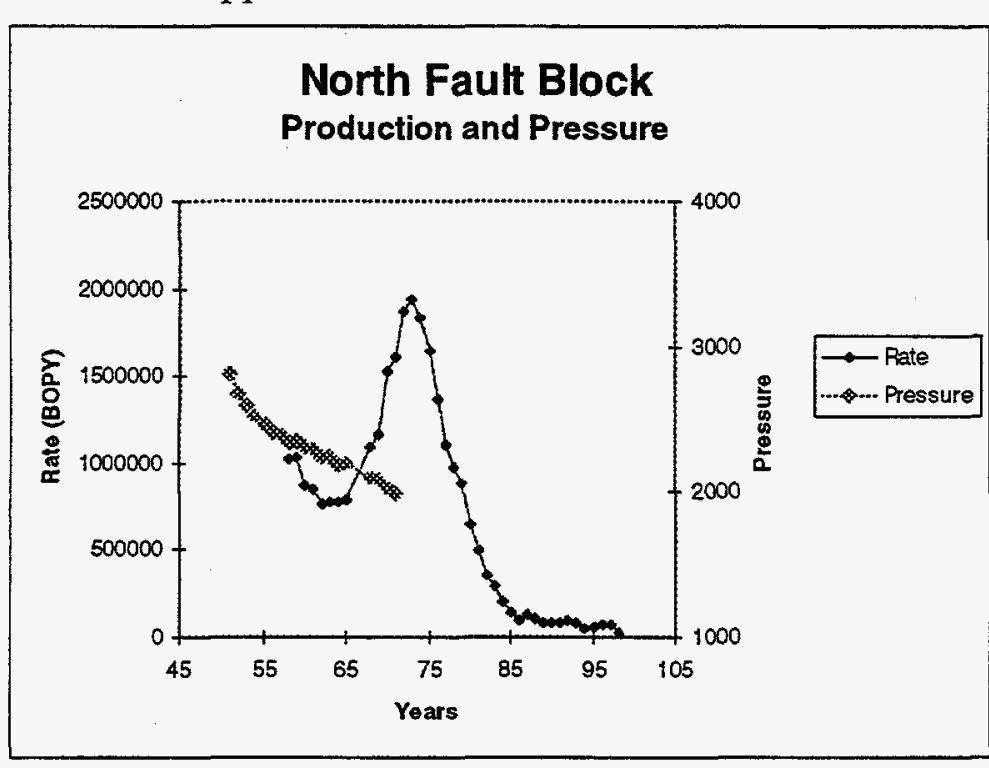

Figure 6. The curves at left show the logarithmic appearing pressure decline characteristic of transient production. There are changes in slope that may indicate interference. These changes seem to take place as the production reaches a maximum, and we take this to indicate the onset of pseudo-steadystate flow. See Raghavan (1993), Lee (1982), Horne (1995).

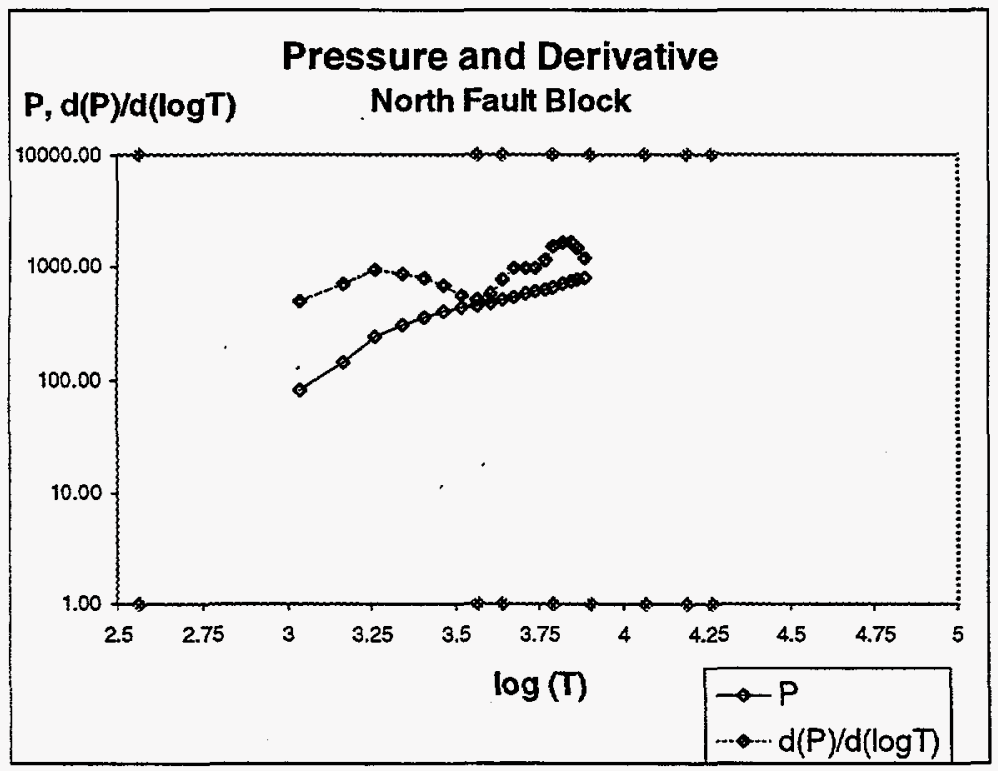

Figure 7. Log-log plot presentation common in well test diagnosis.

$\log (\Delta P)$ and the $\log (t)$ derivative of $P$ tend to confirm the semi-log linear character and slope doubling we saw in Figure 6. The slope doubling indicates interference with a neighbor well or an impermeable barrier. $T$ is days post 1949 . The ticks on the horizontal axes indicate the years 1949 , 1958, 1960, 1965, 1970, 1980, 1990, and 1998.

The derivative shows two possible slope doubling or interference regions and a region of slope decline. In draw-down tests, this decline could be an indication of support from an an active aquifer. It is significant that the first doubling takes place before the sharp increase in production after 1968. The reduction of slope takes place between 1970 and 1980 , when actual production was at a maximum. The apparent pressure support is 
unlikely to be an effect of shut-in wells. This is when production was at its highest. We think the reduction in slope is aquifer support and indicates a strong water drive. This is consistent with the classic aquifer studies on this system (Moore and Truby, 1952), where boundary/closed aquifer effects were seen in the first years of production.

\section{BIHLIOGRAPHY}

Horne, R. 1995: Modern well test analysis a computer aided approach, $2^{\text {nd }}$ Edition, Petroway, Inc.

Lee, J., 1982: Well testing, Soc. Pet. Eng.

Moore, W. D. and Truby, L. G. Jr., 1952: Pressure performance of five fields completed in a common aquifer, Trans. AIME, 195, 297

Technical Committee, 1972: Parameter Study, Phillips Petroleum Co., Unpublished

Petroleum Information Industry Client Server (PIICS, 1997): The PI Well Data System, Petroleum Information Corporation

Raghavan, R., 1995: Well test analysis, Prentice Hall 
APPENDIX I: PRESSURE EVOLUTION DURING THE INITIAL PRODUCTION PHASE IN ANDECTOR FIELD

North Fault Block
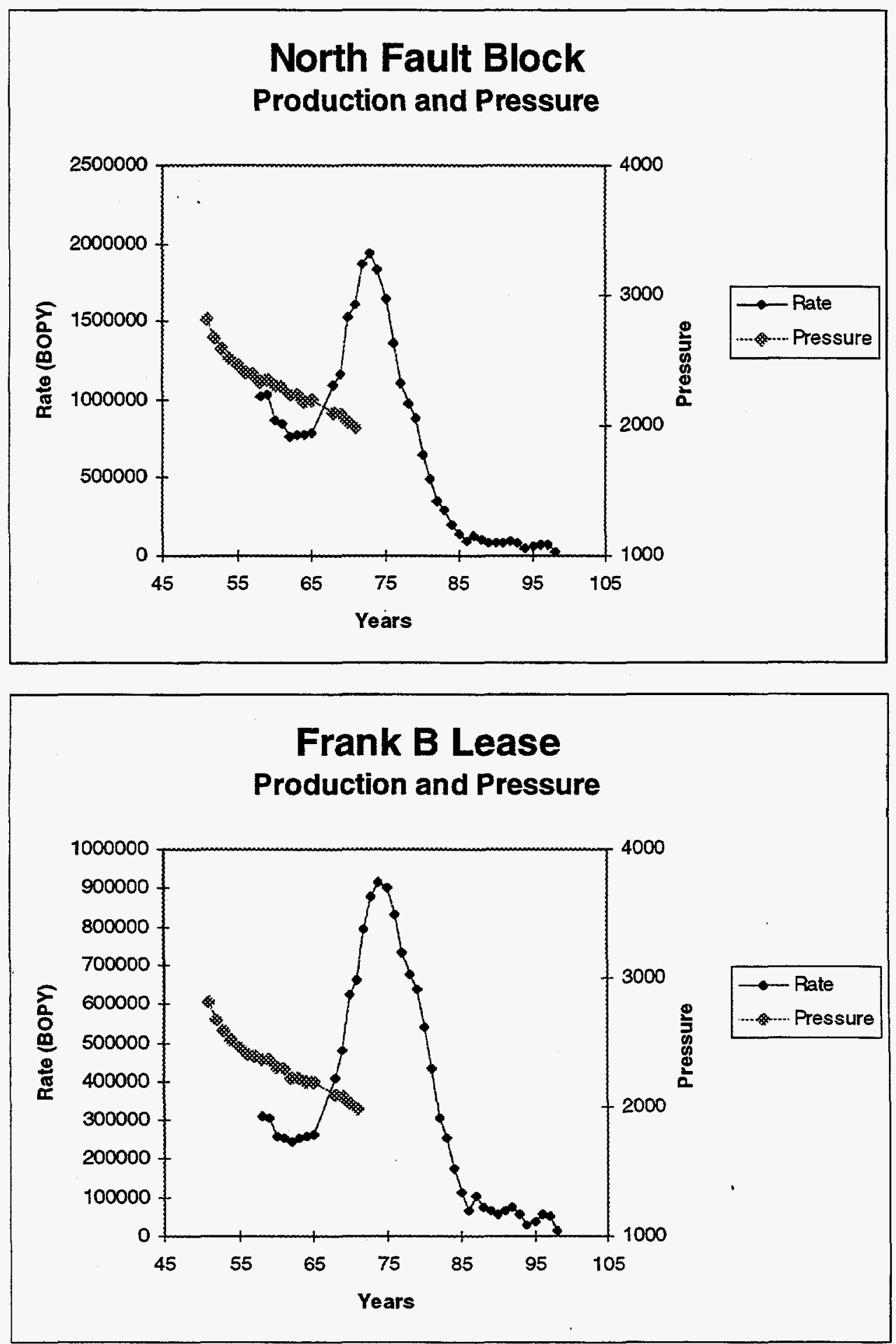

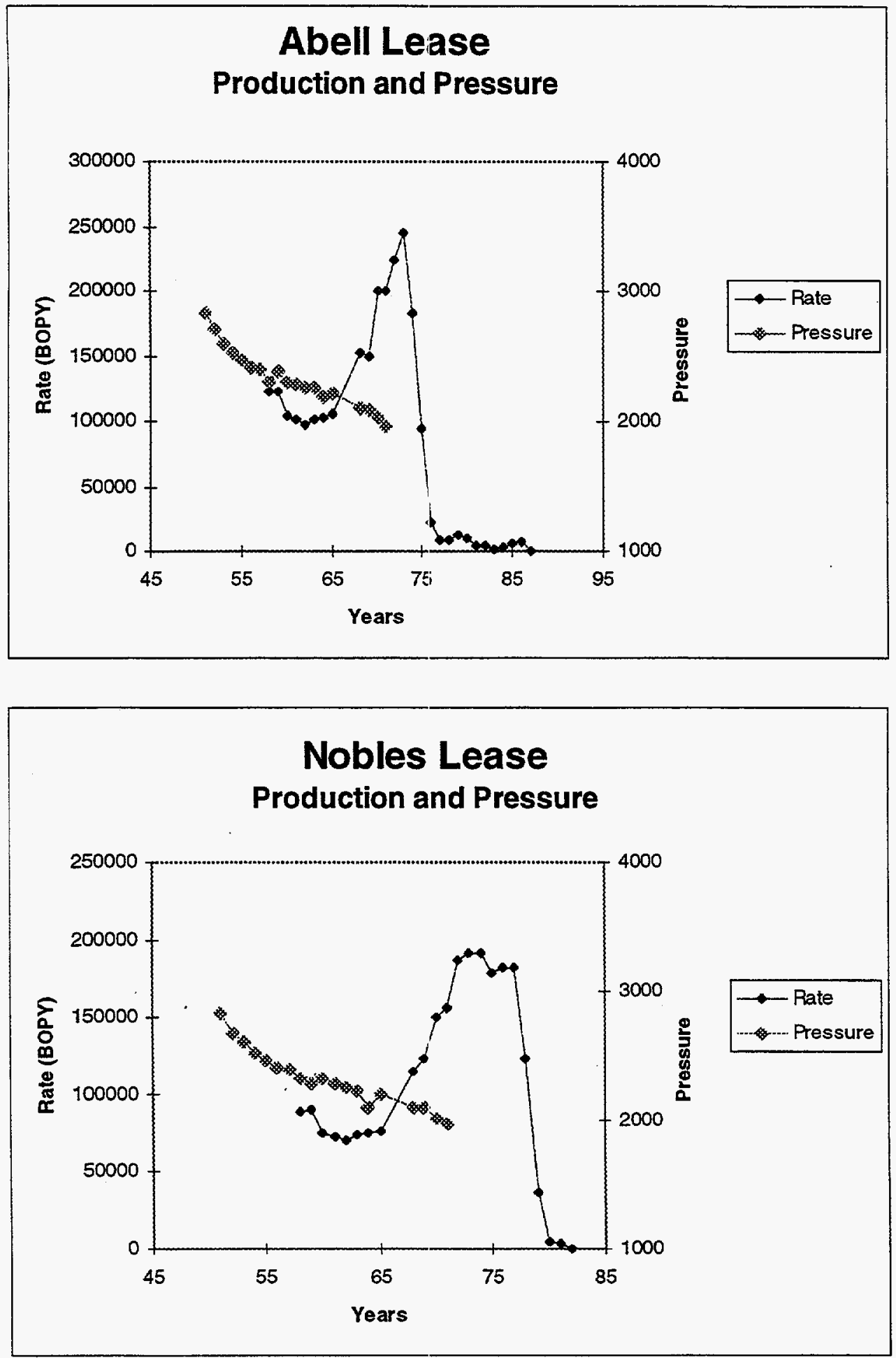
South Fault Block
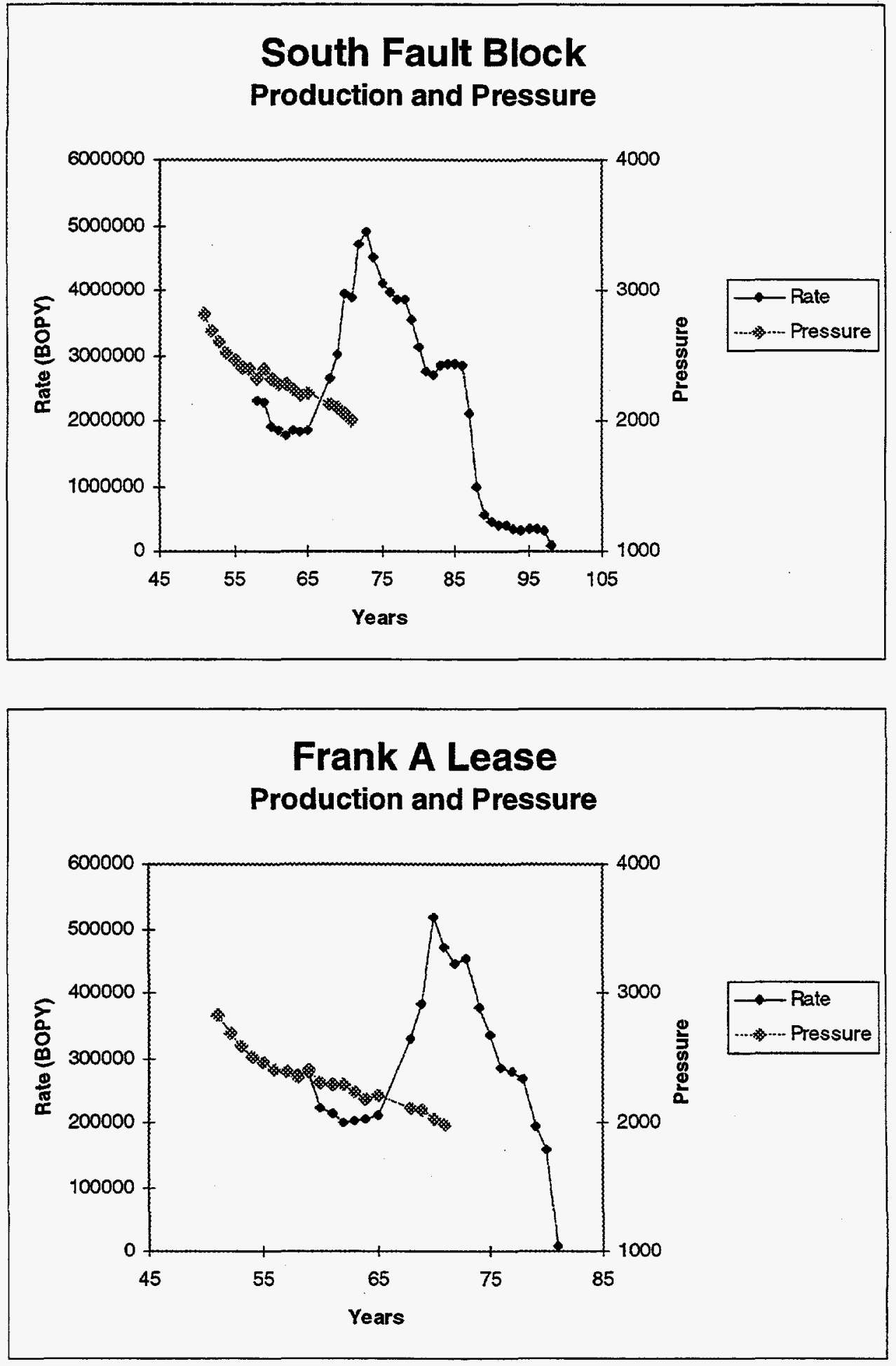


\section{Embar Lease \\ Production and Pressure}
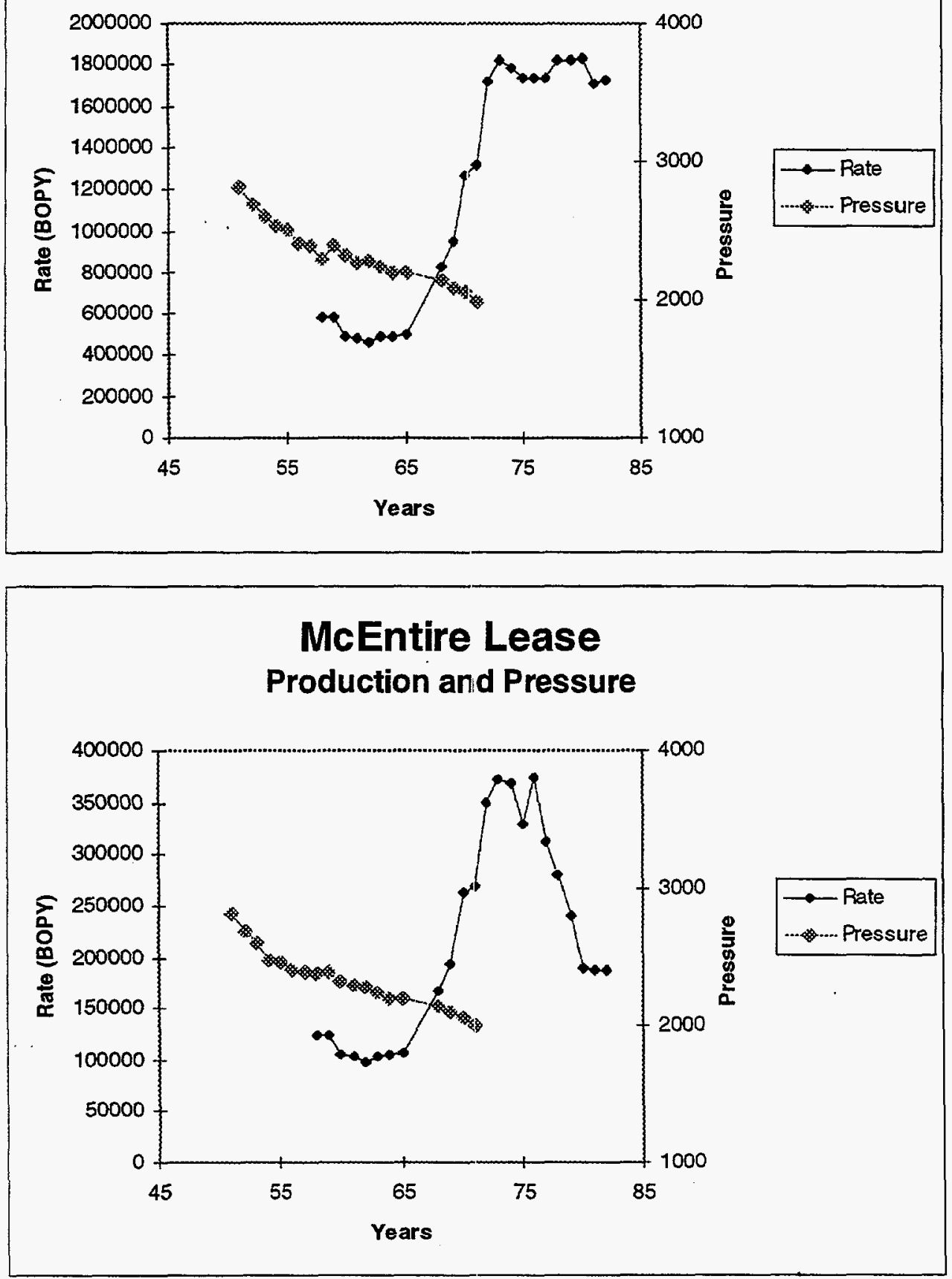


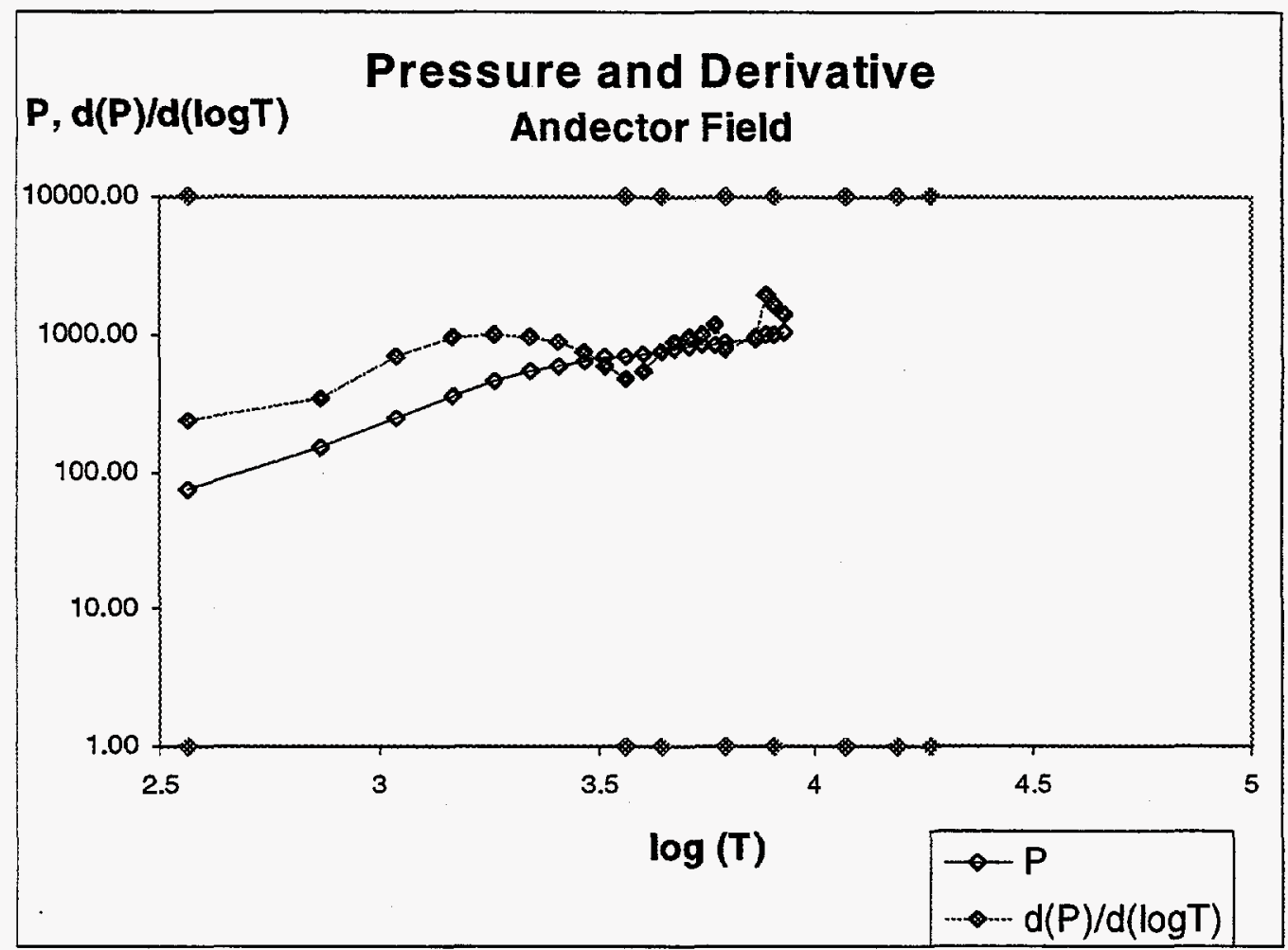

The deriviatives of pressure with respect to $\log \mathrm{T}$ were obtained in two steps. First, the pressure change, $\Delta \mathrm{P}$, was convolved with the series of weights $(1,2,3,2,1)$ and the result divided by 9 to produce a moving average. Then a second order formula for the first derivative was applied to the smoothed data. The results are the lightly shaded curve above. The following graphs present diagnostic plots for the Andector leases in this study. 
North Fault Block
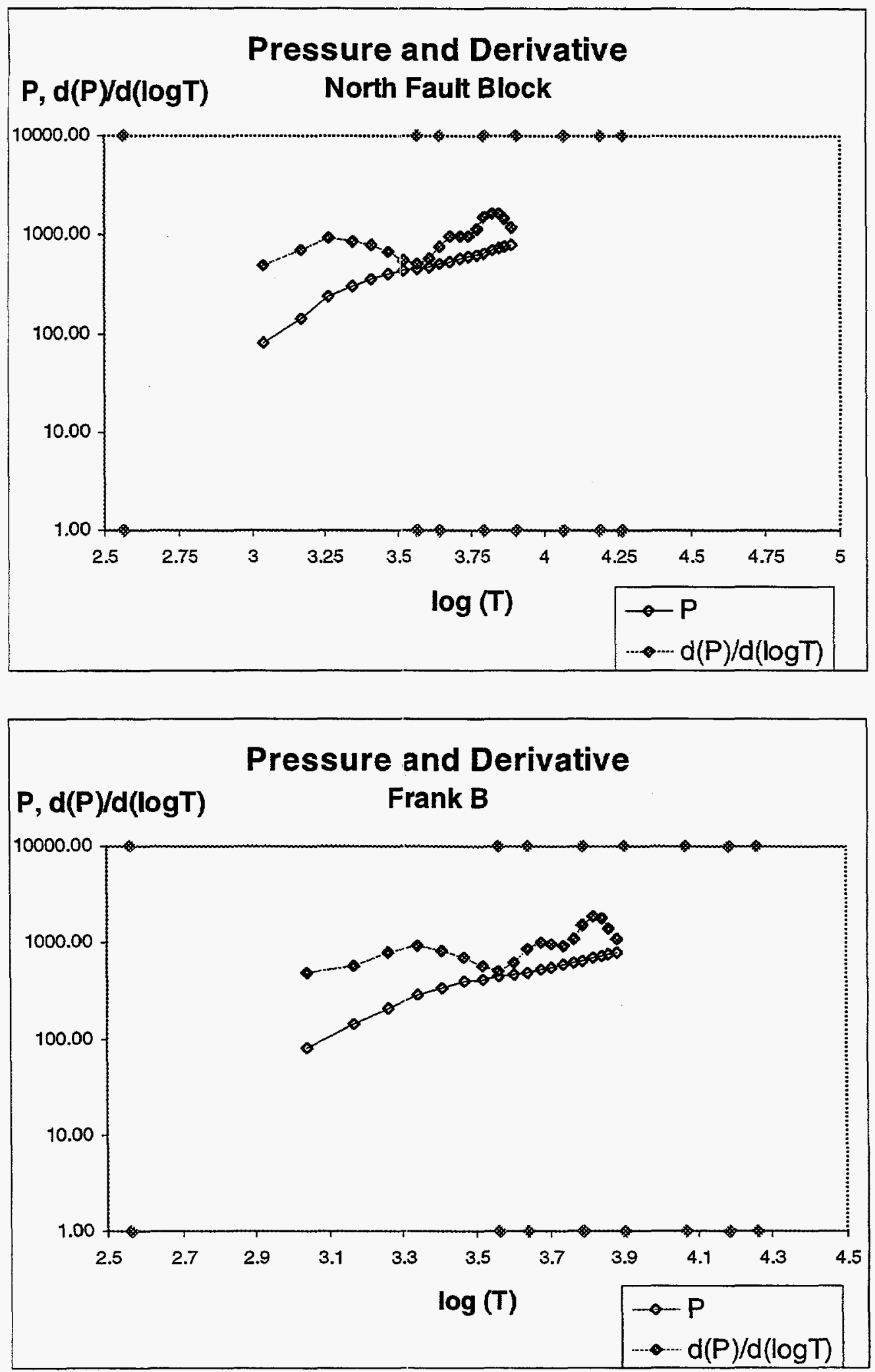

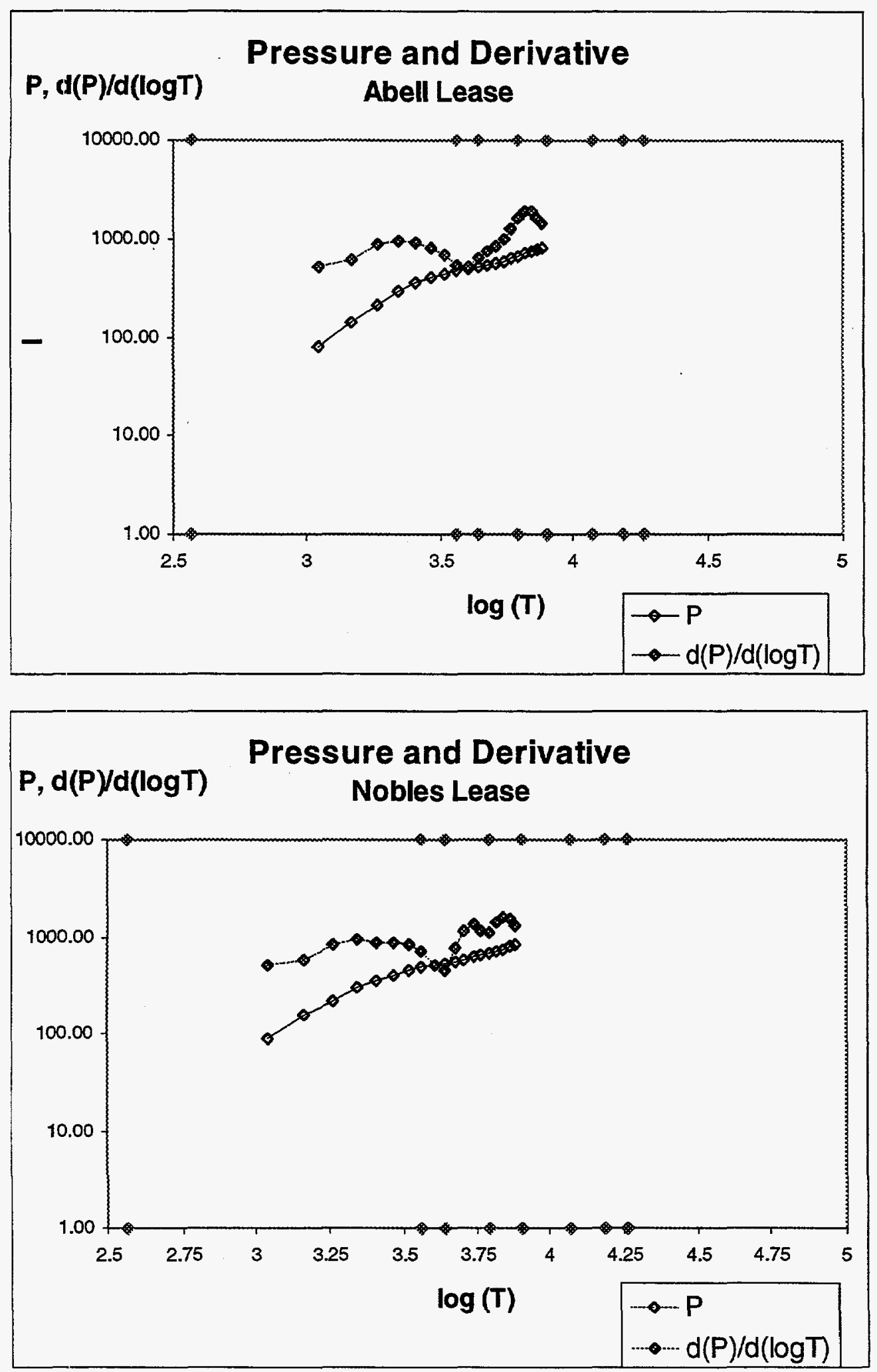
South Fault Block
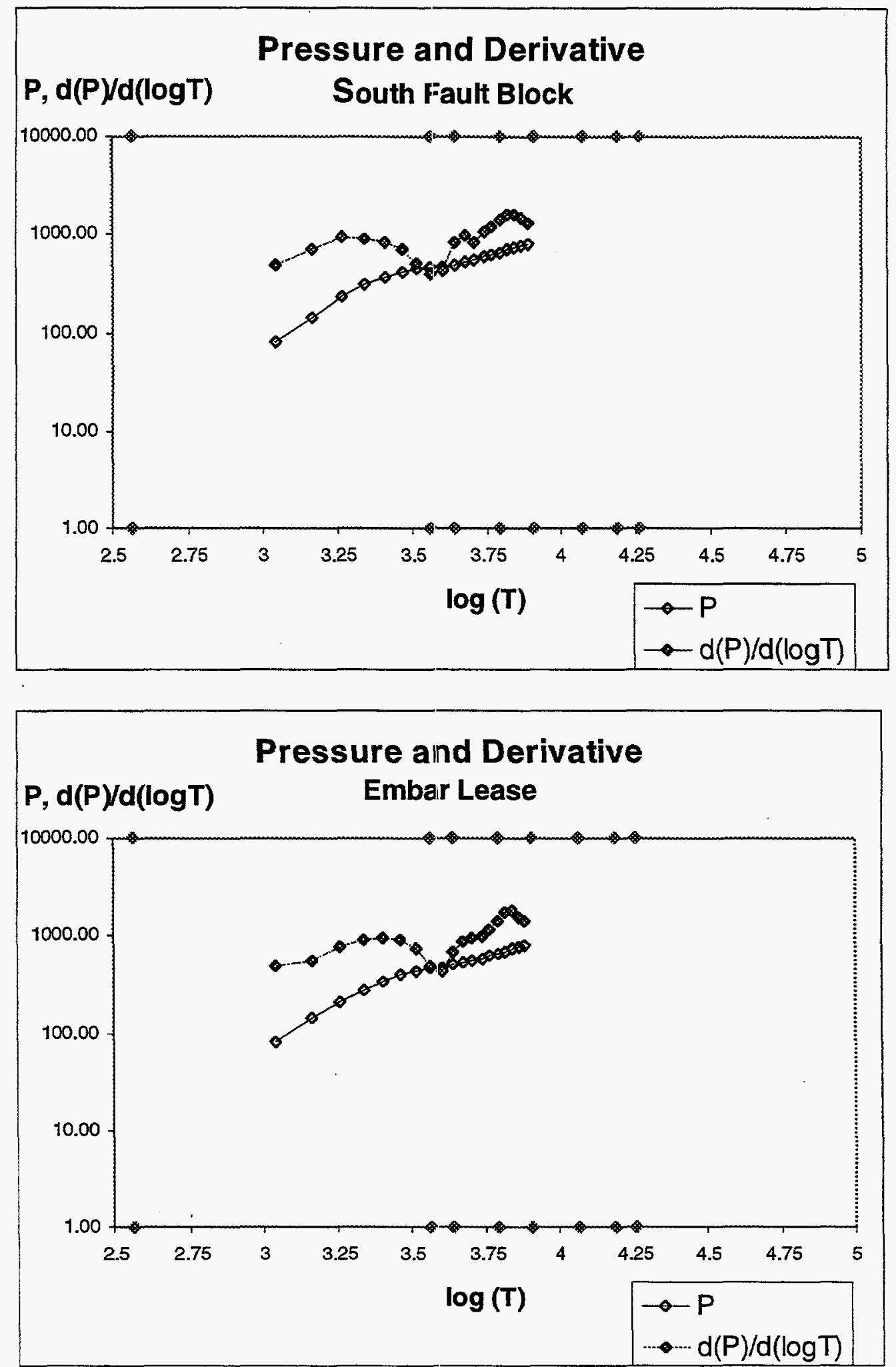


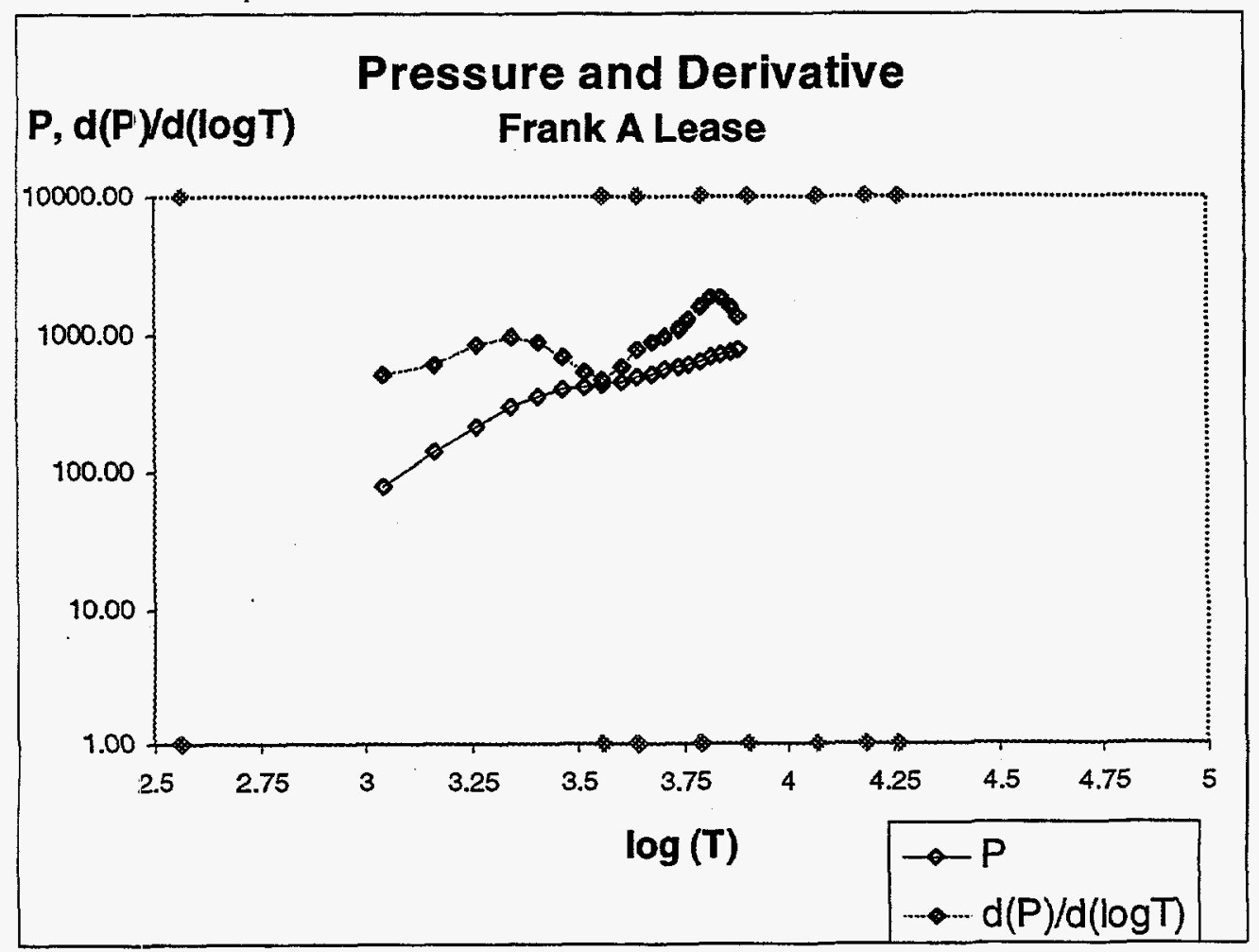

